\title{
Emergency Assessment of Postwildfire Debris-Flow Hazards for the 2011 Motor Fire, Sierra and Stanislaus National Forests, California
}

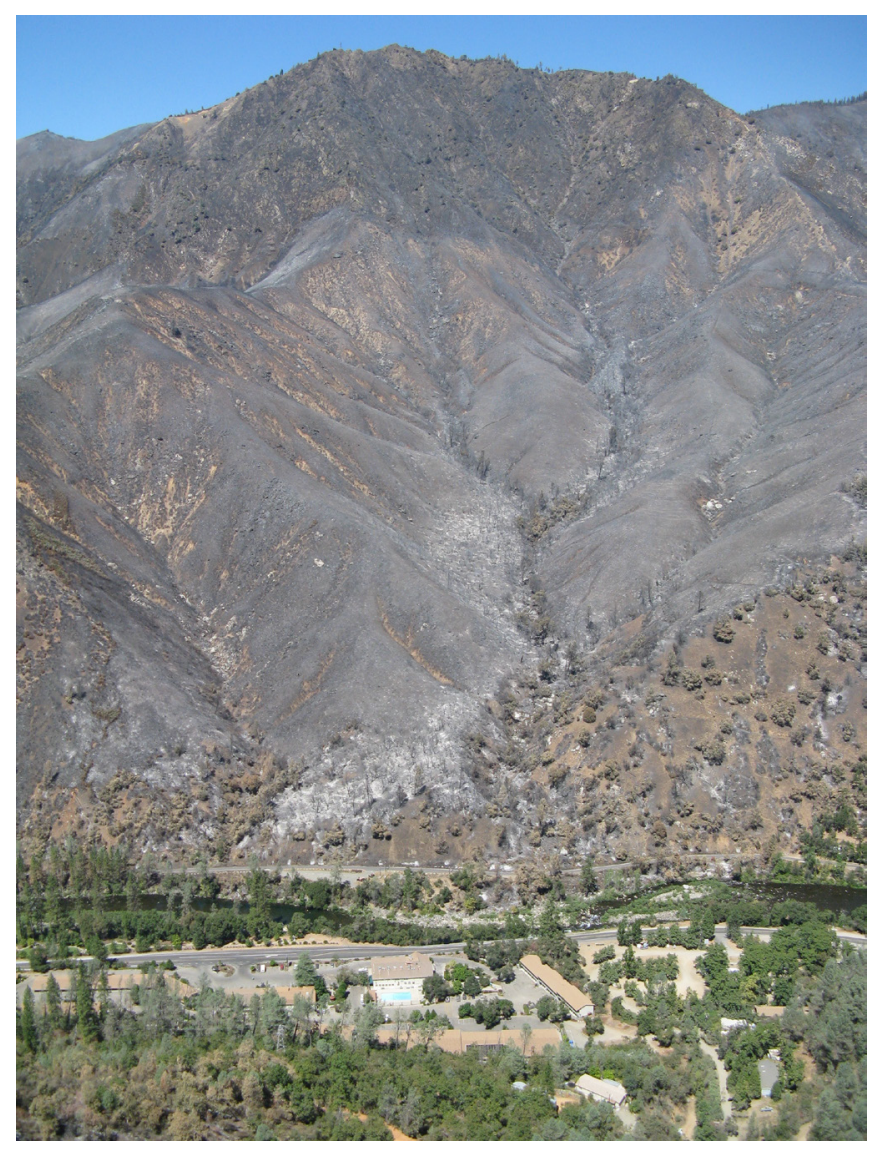

By Susan H. Cannon and John A. Michael

Open-File Report 2011-1251

U.S. Department of the Interior U.S. Geological Survey 


\section{U.S. Department of the Interior \\ KEN SALAZAR, Secretary}

\section{U.S. Geological Survey \\ Marsha K. McNutt, Director}

U.S. Geological Survey, Reston, Virginia: 2011

For product and ordering information:

World Wide Web: http://www.usgs.gov/pubprod

Telephone: 1-888-ASK-USGS

For more information on the USGS-the Federal source for science about the Earth, its natural and living resources, natural hazards, and the environment:

World Wide Web: http://www.usgs.gov

Telephone: 1-888-ASK-USGS

Suggested citation: Cannon, S.H., and Michael, J.A., 2011, Emergency assessment of postwildfire debris-flow hazards for the 2011 Motor Fire, Sierra and Stanislaus National Forests, California: U.S. Geological Survey Open-File Report 2011-1251, 10 p.

Cover photograph: Cranberry Gulch and Trumbull Peak burned by the 2011 Motor fire. Photograph by Jerome DeGraff, USDA Forest Service.

Any use of trade, product, or firm names is for descriptive purposes only and does not imply endorsement by the U.S. Government.

Although this report is in the public domain, permission must be secured from the individual copyright owners to reproduce any copyrighted material contained within this report. 


\section{Contents}

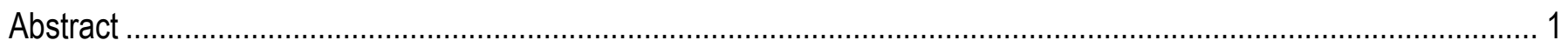

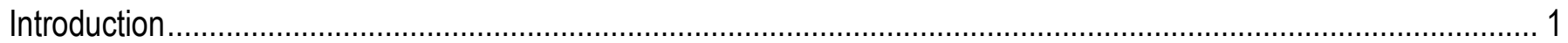

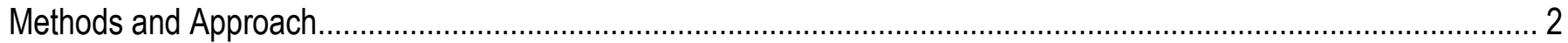

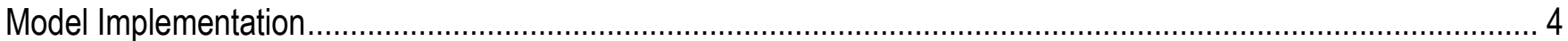

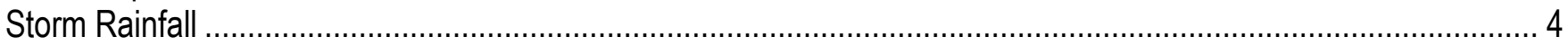

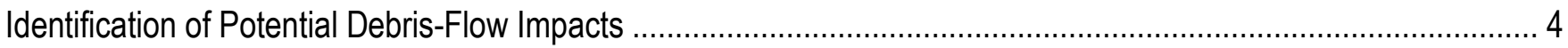

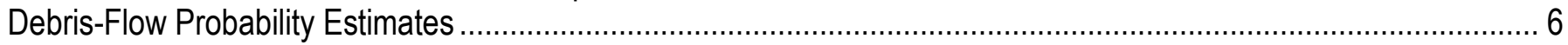

Debris-Flow Volume Estimates........................................................................................................

Combined Relative Debris-Flow Hazard Rankings ....................................................................................... 8

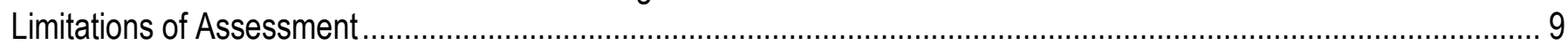

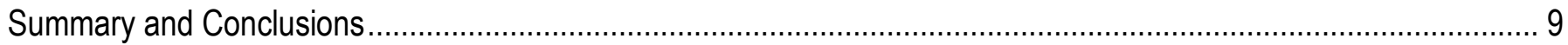

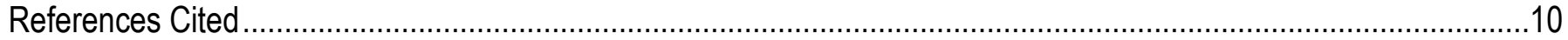

\section{Figures}

1. Map showing location of Motor fire, Sierra and Stanislaus National Forests, California .......................................... 2

2. Probability of debris flow estimated for basins burned by the Motor fire ........................................................... 6

3. Volume of material estimated at the basin mouth for basins burned by the Motor fire ........................................... 7

4. Combined Relative Debris-Flow Hazard Rankings for basins burned by the Motor fire.......................................... 8

\section{Tables}

1. Variables in the debris-flow probability and volume models ....................................................................... 3

2. Basin characteristics, probability and volume estimates, and combined relative hazard rankings........................... 5 


\title{
Emergency Assessment of Postwildfire Debris-Flow Hazards for the 2011 Motor Fire, Sierra and Stanislaus National Forests, California
}

\author{
By Susan H. Cannon and John A. Michael
}

\begin{abstract}
This report presents an emergency assessment of potential debris-flow hazards from basins burned by the 2011 Motor fire in the Sierra and Stanislaus National Forests, Calif. Statistical-empirical models are used to estimate the probability and volume of debris flows that may be produced from burned drainage basins as a function of different measures of basin burned extent, gradient, and soil physical properties, and in response to a 30-minute-duration, 10-year-recurrence rainstorm. Debris-flow probability and volume estimates are then combined to form a relative hazard ranking for each basin. This assessment provides critical information for issuing warnings, locating and designing mitigation measures, and planning evacuation timing and routes within the first two years following the fire.
\end{abstract}

\section{Introduction}

Debris flows can pose substantial hazards to life and property. Fast-moving debris flows generated from recently burned areas are particularly dangerous because they can occur in places where flooding or debris flows have not been observed in the past and can be generated by very little rainfall (Cannon and others, 2008, 2009). In recently burned areas, rainfall that is normally captured and stored by vegetation can run off almost instantly, causing creeks and drainage areas to flood much sooner and with more water during a storm than is expected under unburned conditions. Soils in a burned area can be highly erodible, and so runoff may contain large amounts of ash, mud, boulders, and vegetation. Within and downstream of the burned area, the powerful force of rushing water, soil, and rock can destroy buildings, roadways, culverts, and bridges, and can cause injury or death. In addition, sediment transported by debris flows can degrade water quality and reduce the storage capacities of reservoirs.

The association between wildfire, debris flows, and floods is well established in the southern Sierra Nevada of California (DeGraff, 1994, DeGraff and others, 2011). When fires that consume the vegetation from the steep, rugged canyons are followed by high-intensity rainstorms, destructive floods and debris flows are a common result. For example, in August of 1990, the Arch Rock fire burned canyons above the town of El Portal, which is approximately 6 kilometers $(\mathrm{km})(4$ miles $(\mathrm{mi})$ ) east of the area burned by the Motor fire (fig 1). A multi-day storm in February and March of 1991 generated debris flows that damaged several homes and roadways in the area (DeGraff, 1994) (fig. 1). 


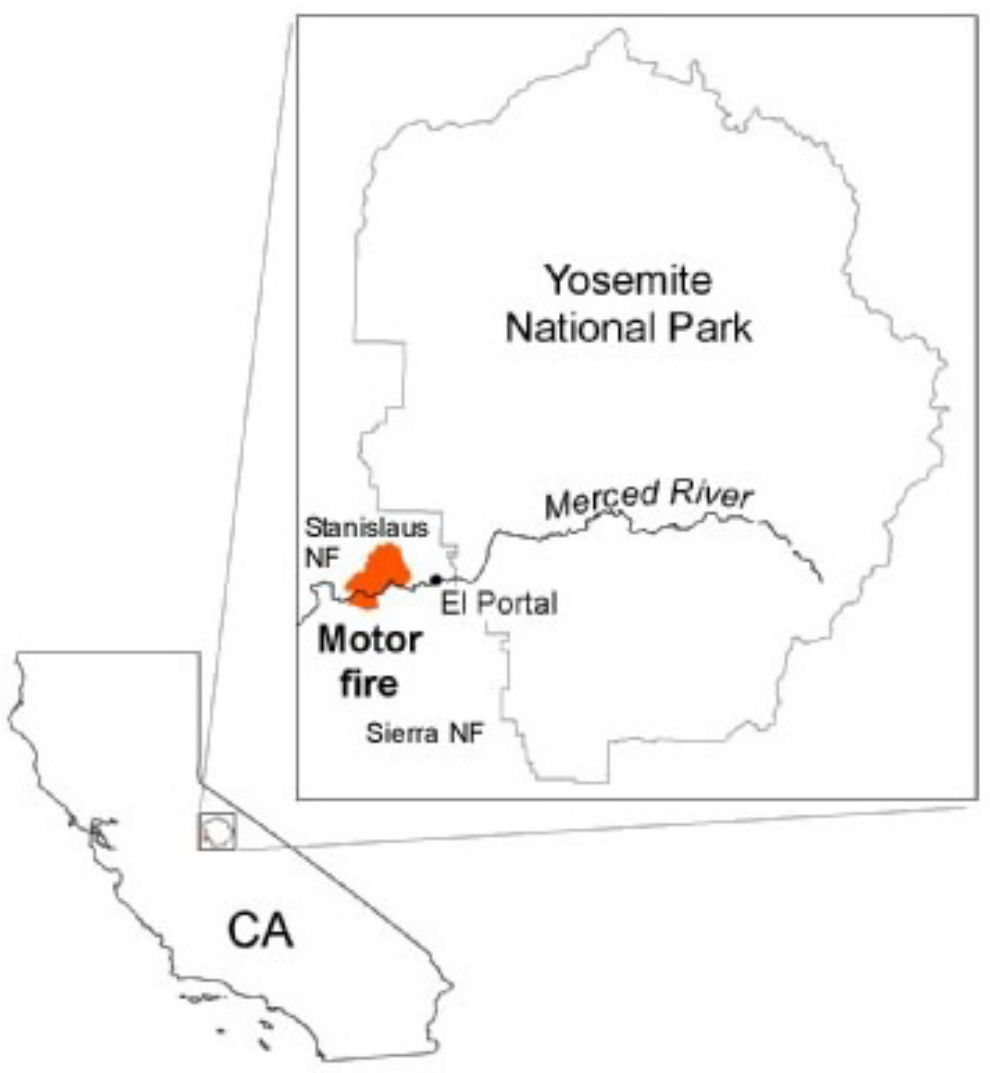

Figure 1. Map showing location of the 2011 Motor fire and Yosemite National Park, Calif. The Merced River is the boundary between the Sierra and Stanislaus National Forests in the area of the fire.

The Motor fire started on August 25, 2011, in the Merced River Canyon of California, just west of the entrance to Yosemite National Park (fig. 1). By the time the fire was contained on September 5, 2011, 2,117 hectares (5,231 acres) of steep, rugged terrain had burned on both sides of the Merced River. The burned area south of the river is in the Sierra National Forest, while the area north of the river is in the Stanislaus National Forest. This report provides an emergency assessment of debris-flow hazards in response to the potential for drainage basins burned by this fire to produce damaging debris flows. This assessment uses a pair of predictive models developed specifically for postwildfire debrisflow processes by Cannon and others (2009) to address two fundamental questions in debris-flow hazard evaluations: What is the likelihood that a given basin will produce debris flows, and how big will the debris flows be? This information is critical for issuing warnings for specific areas, locating and designing mitigation measures, and planning for evacuation timing and routes.

\section{Methods and Approach}

In studies of postfire debris-flow processes throughout the western United States, Cannon and Gartner (2005) demonstrated that the great majority of fire-related debris flows initiate through a process of progressive bulking of storm runoff with sediment eroded both from hillslopes and from channels. Any infiltration-triggered landsliding that may occur in burned basins generally contributes little to the total volume of material transported from the basin (Cannon and others, 2001). These 
findings point to a striking postfire shift from an infiltration-dominated system to one dominated by runoff processes and indicate that methods traditionally used to assess landslide hazards are not appropriate in a postfire environment. Accordingly, it is necessary to use methods that are specifically designed for postfire processes.

For this effort, a pair of statistical-empirical models was used to estimate the probability of a debris flow and the volume of a debris flow from individual drainage basins in response to given storm events (Cannon and others, 2009). The probability model was developed using logistic multipleregression analyses of data from 388 basins in 15 recently burned areas throughout the western United States. Conditions in each basin were quantified using several measures of areal burned extent, basin gradient, soils, and storm rainfall. Statistical analyses were used to identify the variables that most strongly influenced debris-flow occurrence and to build the predictive model (table 1). The model estimates the probability of a debris flow at the basin outlet as a function of conditions within the basin at elevations above that point.

Table 1. Variables in the debris-flow probability and volume models.

\begin{tabular}{|c|c|c|}
\hline & $\begin{array}{l}\text { Probability model } \\
\text { (Cannon and others, 2009) }\end{array}$ & $\begin{array}{l}\text { Volume model } \\
\text { (Gartner and others, 2008) }\end{array}$ \\
\hline Burned Extent & $\begin{array}{l}\text { Percentage of basin area burned at high } \\
\text { and moderate severities }\end{array}$ & $\begin{array}{l}\text { Area of basin burned at high } \\
\text { and moderate severities }\end{array}$ \\
\hline Soil Properties & $\begin{array}{l}\text { Percent clay } \\
\text { Liquid limit }\end{array}$ & None \\
\hline Basin Characteristics & $\begin{array}{l}\text { Percentage of basin area with slopes } \\
\text { greater than or equal to } 30 \text { percent } \\
\text { Basin ruggedness }\end{array}$ & $\begin{array}{l}\text { Basin area with slopes greater } \\
\text { than or equal to } 30 \text { percent }\end{array}$ \\
\hline Storm Rainfall & Average storm intensity & Total storm rainfall \\
\hline
\end{tabular}

A different statistical model was used to estimate the volume of material that could issue from a basin mouth in response to a given storm. This model was developed using multiple linear-regression analyses of data compiled from 55 debris-flow-producing basins burned by eight different fires, where the measured debris-flow volume could be attributed to a single storm (Gartner and others, 2008; Cannon and others, 2009). Volume measurements were based on sediment-retention basin cleanout records and field measurements. As with the probability model, statistical analyses were used to identify the variables that most strongly influenced debris-flow volume and to build the predictive model (table 1).

Debris-flow hazards within a given basin can also be represented by a combination of both probability of occurrence and volume (Cannon and others, 2009). For example, the most hazardous basins will show both the highest probabilities of occurrence and the largest estimated volumes of material. Slightly less hazardous basins would show a combination of either relatively low probabilities and larger volume estimates or high probabilities and smaller volume estimates. The lowest relative hazard would be shown by basins where both the lowest probabilities and the smallest volumes are identified. For this assessment, the estimated values of debris-flow probability and volume are categorized into relatively ranked classes, and these classes are combined to calculate a "Combined Relative Debris-Flow Hazard Ranking." This ranking identifies a possible range of responses from basins that are most prone to producing debris flows with the largest volumes, to basins with the lowest probabilities that will likely produce the smallest events. 


\section{Model Implementation}

The two statistical models were implemented by first delineating the basins to be evaluated within the burned perimeter using topographic information derived from the 10-meter $(\mathrm{m})$ digital elevation model (DEM) and geographic information system (GIS) hydrological tools. Basin outlets were positioned at breaks in slope along California Highway 140 and Incline Road (Mariposa County Road 13), which parallel the Merced River to the south and north, respectively, as well as at the perimeter of the area burned by the Motor fire (fig. 2). Twenty-five basins were identified for assessment within the area burned by the Motor fire. The areas of these basins ranged between 0.07 square kilometers $\left(\mathrm{km}^{2}\right)$ and $6 \mathrm{~km}^{2}$. These values fall within the range of basin sizes used in the development of the regression models (table 2) (Cannon and others, 2009). Measures of the physical properties of soils within each basin were obtained from the STATSGO soils database (Schwartz and Alexander, 1995). If more than one soil unit occurred within a given basin, a spatially weighted average of the soil parameter values was calculated. The map of soil-burn severity provided by the U.S. Department of Agriculture (USDA) Forest Service Burned Area Emergency Response (BAER) Team and USDA Forest Service Remote Sensing Applications Center (RSAC) BAER Image Support Team (http://activefiremaps.fs.fed.us/baer/download.php) was used to identify the areas burned at high and moderate severities within each basin.

\section{Storm Rainfall}

Postwildfire debris flows in the Sierra Nevada have been reported to have been triggered in response to bursts of high-intensity rainfall during a long-duration, low-intensity rainstorm (DeGraff, 1994). Cannon and others (2008) have found that most debris flows are triggered in response to shortrecurrence period storms, while Kean and others (2011) demonstrated that periods of intense rain over less than 30 minutes were most likely to generate postwildfire debris flows. To characterize the effects of these rainfall conditions, we estimated the probability that a given basin will produce debris flows and a possible debris-flow volume at the basin outlet in response to a 30-minute-duration, 10-yearrecurrence rainstorm of 0.73 inches (in) (Bonnin and others, 2006). Any storm with a 10-yearrecurrence interval is considered to have a 10 percent chance of occurring in any given year.

\section{Identification of Potential Debris-Flow Hazards}

Maps of each of the burned areas viewed at approximately 1:6,000 scale on the Geospatial Multi-Agency Coordination (GeoMAC) web site (http://www.geomac.gov/) and Google Earth were used to identify potential rivers, canyons, roads, and structures that may be damaged by debris flows. This survey cannot be considered all-inclusive at all scales; site-specific evaluations are necessary to identify potential hazards to individual properties or structures. 
Table 2. Basin characteristics, probability and volume estimates, and combined relative-hazard rankings. Data for basins located in the Sierra National Forest are indicated by shading. All other basins are located in the Stanislaus National Forest. [km², square kilometers; $\mathrm{m}^{3}$, cubic meters; $\geq$, greater than or equal to]

\begin{tabular}{|c|c|c|c|c|c|c|c|c|c|}
\hline $\begin{array}{l}\text { Basin } \\
\text { ID }\end{array}$ & $\begin{array}{c}\text { Basin } \\
\text { area } \\
\left(\mathrm{km}^{2}\right)\end{array}$ & $\begin{array}{c}\text { Basin area } \\
\text { burned at } \\
\text { high and } \\
\text { moderate } \\
\text { severity } \\
\left(\mathrm{km}^{2}\right)\end{array}$ & $\begin{array}{c}\text { Soil clay } \\
\text { content } \\
\text { (percent) }\end{array}$ & $\begin{array}{c}\text { Soil } \\
\text { liquid } \\
\text { limit }\end{array}$ & $\begin{array}{c}\text { Basin area } \\
\text { with slopes } \\
\geq 30 \text { percent } \\
\left(\mathrm{km}^{2}\right)\end{array}$ & $\begin{array}{c}1 \text { Basin } \\
\text { ruggedness }\end{array}$ & $\begin{array}{c}\text { Probability } \\
\text { of debris } \\
\text { flow } \\
\text { (percent) }\end{array}$ & $\begin{array}{c}\text { Volume } \\
\text { of debris } \\
\text { flow } \\
\left(\mathrm{m}^{3}\right)\end{array}$ & $\begin{array}{c}{ }^{2} \text { Combined } \\
\text { relative } \\
\text { hazard } \\
\text { ranking }\end{array}$ \\
\hline 1 & 0.11 & 0.10 & 18.4 & 28.1 & 0.11 & 1.34 & 63 & 1,400 & 3 \\
\hline 2 & 0.32 & 0.14 & 18.7 & 28.2 & 0.32 & 1.18 & 13 & 2,800 & 2 \\
\hline 3 & 0.10 & 0.03 & 18.5 & 28.1 & 0.09 & 1.38 & 3 & 1,100 & 2 \\
\hline 4 & 0.34 & 0.25 & 19.3 & 28.4 & 0.33 & 1.14 & 46 & 3,100 & 3 \\
\hline 5 & 0.93 & 0.34 & 18.4 & 28.1 & 0.92 & 0.89 & 12 & 6,100 & 2 \\
\hline 6 & 0.93 & 0.39 & 19.1 & 28.4 & 0.92 & 1.06 & 14 & 6,300 & 2 \\
\hline 7 & 0.50 & 0.39 & 19.7 & 28.6 & 0.48 & 1.12 & 55 & 4,300 & 3 \\
\hline 8 & 0.12 & 0.09 & 19.7 & 28.6 & 0.12 & 1.18 & 49 & 1,500 & 3 \\
\hline 9 & 0.11 & 0.11 & 19.7 & 28.6 & 0.11 & 1.46 & 73 & 1,400 & 3 \\
\hline 10 & 0.16 & 0.15 & 19.7 & 28.6 & 0.16 & 1.60 & 66 & 1,800 & 3 \\
\hline 11 & 0.25 & 0.24 & 19.7 & 28.6 & 0.24 & 1.34 & 76 & 2,600 & 3 \\
\hline 12 & 0.40 & 0.37 & 19.3 & 28.4 & 0.39 & 1.05 & 78 & 3,700 & 3 \\
\hline 13 & 0.28 & 0.26 & 19.5 & 28.5 & 0.27 & 1.20 & 75 & 2,800 & 3 \\
\hline 14 & 0.17 & 0.17 & 19.7 & 28.6 & 0.16 & 0.94 & 86 & 1,900 & 4 \\
\hline${ }^{3} 15$ & 1.93 & 1.55 & 19.7 & 28.6 & 1.82 & 0.75 & 70 & 14,600 & 4 \\
\hline 16 & 0.22 & 0.21 & 19.7 & 28.6 & 0.18 & 0.66 & 84 & 2,100 & 4 \\
\hline 17 & 0.28 & 0.24 & 19.3 & 28.5 & 0.22 & 0.90 & 71 & 2,400 & 3 \\
\hline 18 & 0.75 & 0.62 & 22.7 & 31.7 & 0.73 & 0.85 & 55 & 6,100 & 3 \\
\hline${ }^{4} 19$ & 6.14 & 4.48 & 23.4 & 32.6 & 5.94 & 0.49 & 51 & 54,600 & 3 \\
\hline 20 & 0.22 & 0.19 & 18.4 & 28.1 & 0.21 & 1.30 & 64 & 2,300 & 3 \\
\hline 21 & 1.10 & 0.58 & 18.4 & 28.1 & 1.09 & 0.99 & 24 & 7,700 & 2 \\
\hline 22 & 0.07 & 0.07 & 18.4 & 28.1 & 0.07 & 1.54 & 66 & 1,100 & 3 \\
\hline 23 & 0.17 & 0.01 & 18.4 & 28.1 & 0.16 & 1.08 & 2 & 1,600 & 2 \\
\hline 24 & 0.12 & 0.09 & 18.4 & 28.1 & 0.12 & 1.16 & 48 & 1,500 & 3 \\
\hline 25 & 0.33 & 0.10 & 18.4 & 28.1 & 0.33 & 1.16 & 6 & 2,700 & 2 \\
\hline
\end{tabular}

${ }^{\mathrm{T}}$ Calculated as the change in basin elevation divided by the square root of the basin area (Melton, 1965).

${ }^{2}$ Possible rankings range from 1 to 5 , with a higher ranking indicating a higher potential hazard. No values of 1 or 5 were calculated for basins burned by the Motor fire.

${ }^{3}$ Cranberry Gulch

${ }^{4}$ Dry Gulch 


\section{Debris-Flow Probability Estimates}

In response to 0.73 in of rain falling in a 30-minute period, probabilities of debris-flow occurrence greater than 80 percent were estimated for the two basins (14 and 16) flanking Cranberry Gulch (fig. 2, table 2). These high values reflect the combined effects of the basins being nearly completely burned at high and moderate severities and the steep slopes within these basins. Debris flows generated from these two basins may directly impact Incline Road and possibly travel into the Merced River. Those basins for which the probability of debris flow is estimated to be between 61 and 80 percent may impact Incline Road as well as Highway 140 and the Merced River at and downstream of those basins (fig. 2, table 2). Debris-flow probabilities between 41 and 60 percent are estimated for basins that may affect Incline Road, Highway 140, the Merced River, structures immediately downstream from Basin 8, and Moss Canyon (fig. 2, table 2). It is estimated that debris flows generated from basins for which debris-flow probabilities are less than 40 percent could affect Incline Road, California Highway 140, the Merced River, and Moss Canyon at and downstream of those basins (fig. 2, table 2).

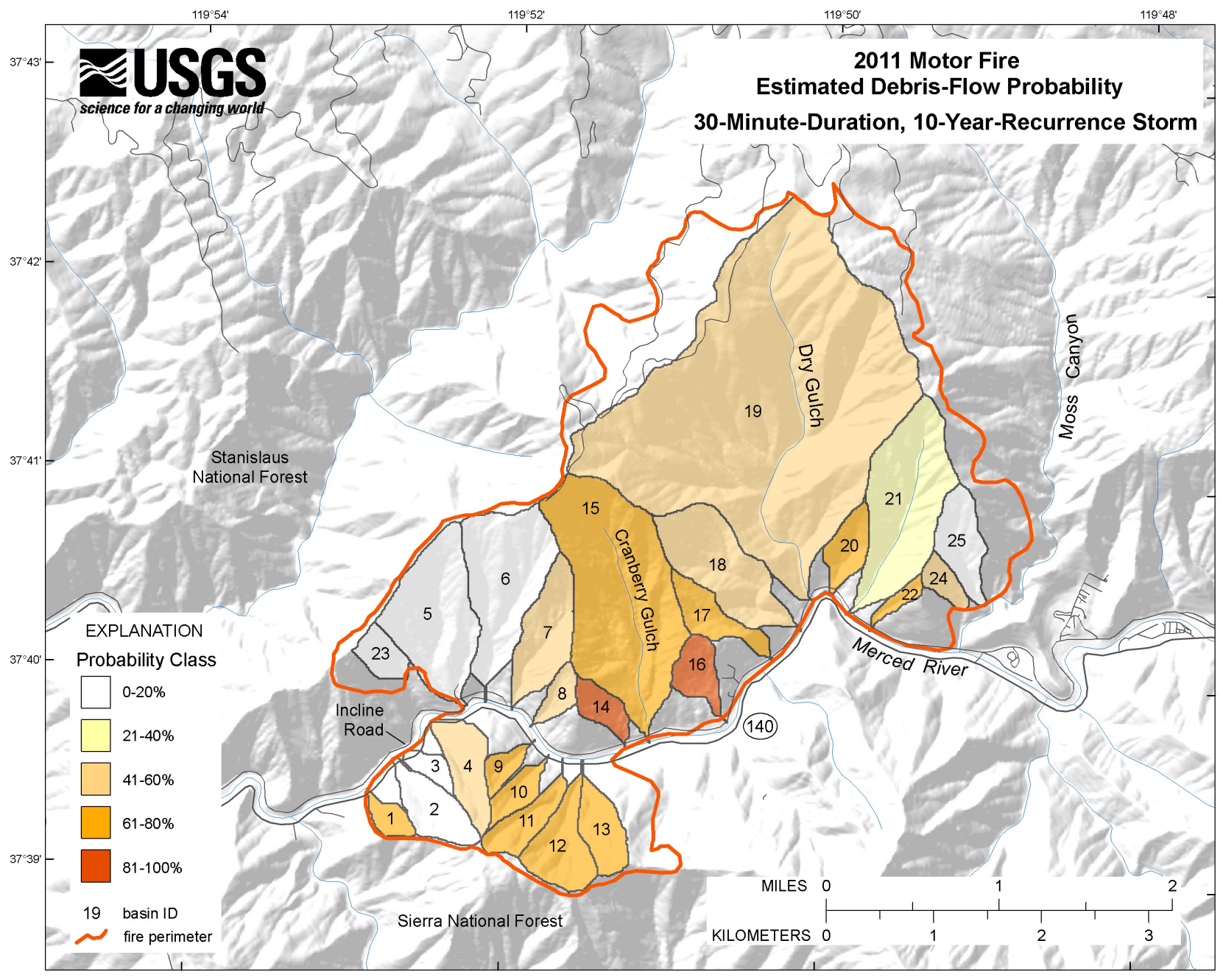

Figure 2. Probability of debris-flow occurrence estimated for basins burned by the Motor fire, if that area were affected by the 30-minute-duration, 10-year-recurrence storm of 0.73 inches (Bonnin and others, 1994). 


\section{Debris-Flow Volume Estimates}

In response to 0.73 in of rainfall in 30 minutes, debris-flow volumes between 10,001 and $100,000 \mathrm{~m}^{3}$ were estimated for Dry and Cranberry Gulches (basins 14 and 16) (fig. 3, table 2). These volumes of material are sufficiently large to impact Incline Road and travel into the Merced River. It is not known if this amount of material is sufficient to dam the river, and this issue requires further attention. Debris-flow volumes between 1,001 and $10,000 \mathrm{~m}^{3}$ were estimated for the remaining 23 basins (fig. 3, table 2). Debris flows at and downstream of these basins could potentially affect Incline Road, California Highway 140, the Merced River, structures downstream of Basin 8, and Moss Canyon.

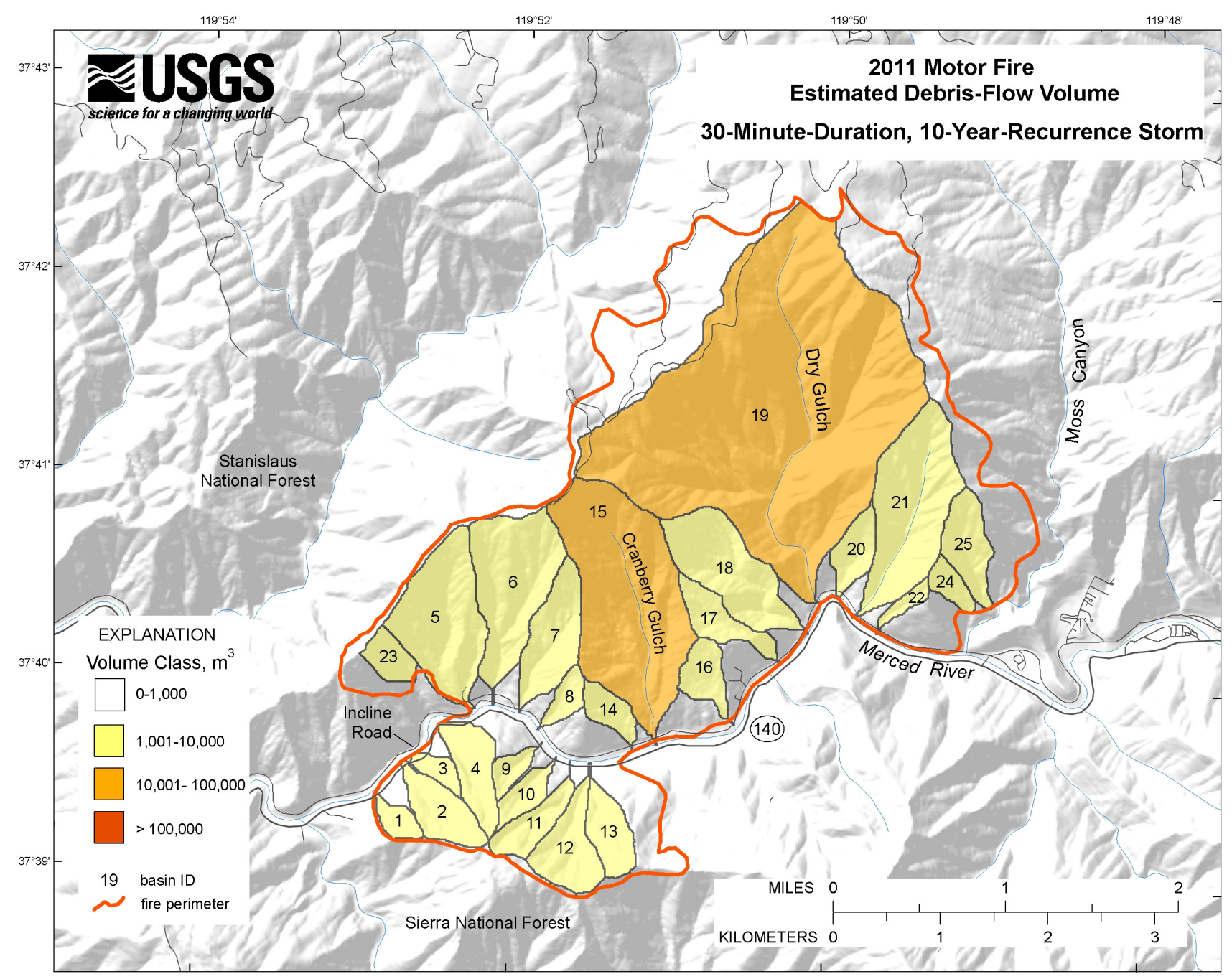

Figure 3. Volume of debris-flow material estimated at the basin mouth for basins burned by the Motor fire, if that basin were affected by the 30-minute-duration, 10-year-recurrence storm of 0.73 inches (Bonnin and others, 1994). ( $\mathrm{m}^{3}$, cubic meters) 


\section{Combined Relative Debris-Flow Hazard Rankings}

When debris-flow hazards were considered as a combination of both probability and volume, we found that in response to the 30-minute-duration, 10-year-recurrence storm, Cranberry Gulch and the two small basins on either side (14 and 16) showed the second highest possible Combined Relative Debris-Flow Hazard Ranking (on a scale of 1-5) (fig. 4). These rankings reflect hazardous conditions within and immediately downstream from these basins, where debris flows may impact Incline Road and the Merced River. The third and fourth highest Combined Relative Debris-Flow Hazard Rankings were estimated for the remaining basins. Debris flows at and downstream from these basins could affect Incline Road, California Highway 140, the Merced River, structures downstream of Basin 8, and Moss Canyon.

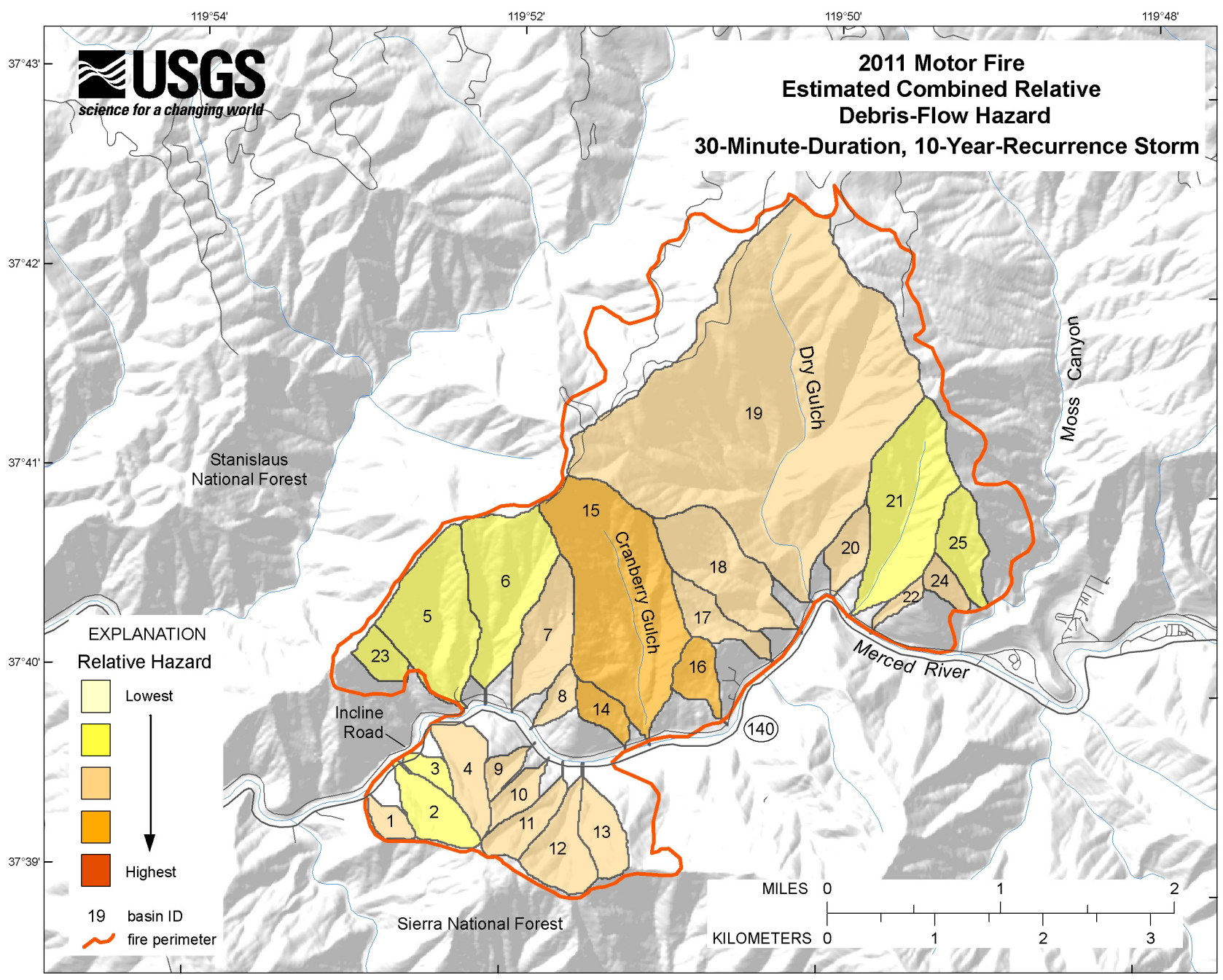

Figure 4. Combined Relative Debris-Flow Hazard Ranking for basins burned by the Motor fire, if that area were affected by a 30-minute-duration, 10-year-recurrence storm of 0.73 inches (Bonnin and others, 1994). Possible relative hazard rankings range from 1 to 5 , and higher rankings indicate a higher potential hazard. No values of 1 or 5 were calculated for basins burned by the Motor fire. 


\section{Limitations of Assessment}

Storms producing greater rainfall accumulations and intensities, or of longer duration than those evaluated in this assessment, could present more severe hazards than those accounted for in figures 2-4. In addition, the assessments presented here refer only to postfire debris flows; the hazards from flash flooding will require a separate assessment. Site-specific evaluations are necessary to identify potential hazards for individual properties or structures, and further assessment is necessary to characterize how debris flows generated from the tributary canyons might affect the Merced River.

The parameters included in the models used in this assessment are considered to be first-order effects on debris-flow generation that can be rapidly evaluated immediately after a fire. Conditions other than those used in the models - for example, the amount of sediment stored in a canyon - could also affect debris-flow production. Data necessary to evaluate such effects, however, are not currently available.

The potential for debris-flow activity decreases with time as revegetation stabilizes hillslopes and stored sediment is removed from canyons. Experience in recently burned areas and a compilation of information on postfire runoff events reported in the literature from throughout the western United States (Gartner and others, 2005) both indicate that, with normal rainfall conditions, most debris-flow activity occurs within about two years following a fire. If dry conditions prevent sufficient regrowth of vegetation, this recovery period will be longer. We conservatively estimate that the assessment presented here might be applicable for as much as two years after the fire. However, substantial hazards from flash flooding could remain for many years after a fire.

Finally, this work is preliminary and is subject to revision. It is being provided owing to the need for timely "best science" information. This assessment is provided on the condition that neither the U.S. Geological Survey nor the United States Government may be held liable for any damages resulting from the authorized or unauthorized use of the assessment.

\section{Summary and Conclusions}

For this assessment, we estimated the probability and volume of debris-flow production from drainage basins burned by the Motor fire in the Sierra and Stanislaus National Forests, Calif., in response to a 30-minute-duration, 10-year-recurrence rainstorm. For each of the 25 drainage basins identified within the burned area, we used a set of multivariate statistical models to estimate (1) the probability of debris-flow occurrence at the basin outlet and (2) the volume of material expected at this location. These qualities were estimated as combinations of different measures of the upstream contributing area burned extent, gradient, and material properties. Within the area burned by the Motor fire, and in response to the 30-minute-duration, 10-year-recurrence storm, drainage basin conditions resulted in estimates of debris-flow probabilities with a likelihood greater than 80 percent for the outlets of the two basins that flank Cranberry Gulch, and debris-flow volumes between 10,001 and 100,000 $\mathrm{m}^{3}$ for the outlets of both Cranberry and Dry Gulches. When these findings are combined into a Relative Debris Flow Hazard Ranking, we identified Cranberry Gulch and the two flanking basins as the basins with the highest probability of producing the largest events. These findings indicate the greatest postwildfire debris-flow impacts may be to Incline Road and the Merced River at and downstream of these basins. The assessment also indicates potential debris-flow impacts to Highway 140, Moss Canyon, and the structures below Basin 8 at any number of locations. We here provide critical information for postwildfire decision making within the first two winters following the fires, including, 
but not restricted to, issuing warnings for specific areas, locating and designing mitigation measures, and planning evacuation timing and routes.

\section{References Cited}

Bonnin, G.M., Martin, D., Lin, B., Parzybok, T., Yekta, M., and Riley, D., 2006, Precipitationfrequency atlas of the United States: Silver Spring, Md., NOAA, National Weather Service, National Oceanic and Atmospheric Administration Atlas 14, v. 1, version 4: accessed online September 5, 2011, at http://hdsc.nws.noaa.gov/hdsc/pfds/sa/sca_pfds.html.

Cannon, S.H., Gartner, J.E., Rupert, M.G., Michael, J.A., Rea, A.H., Parrett, C., 2009, Predicting the probability and volume of post-wildfire debris flows in the intermountain west, USA: Geological Society of America Bulletin, v. 122, no. 1/2, p. 127-144.

Cannon, S.H., and Gartner, J.E., 2005, Wildfire-related debris flow from a hazards perspective, chap. 15 of Jakob, Matthias, and Hungr, Oldrich, eds., Debris-Flow Hazards and Related Phenomena:

Chichester, U.K., Springer-Praxis Books in Geophysical Sciences, p. 321-344.

Cannon, S.H., Gartner, J.E., Wilson, R.C., Bowers, J.C., and Laber, J.L., 2008, Storm rainfall conditions for floods and debris flows for recently burned areas in southwestern Colorado and southern California: Geomorphology, v. 96, p. 250-269.

Cannon, S.H., Kirkham, R.M., and Parise, Mario, 2001, Wildfire-related debris-flow initiation processes, Storm King Mountain, Colorado: Geomorphology, v. 39, no. 3-4, p. 171-188.

DeGraff, J.V., 1994, The geomorphology of some debris flows in the southern Sierra Nevada, California: Geomorphology, v. 10, p. 231-252.

DeGraff, J.V., Wagner, D., Gallegos, A.J., DeRose, M., Shannon, C. and Ellsworth, T., 2011, The remarkable occurrence of large rainfall-induced debris flows at two different locations on July 12, 2008, Sierra Nevada, CA: Landslides, v. 8, no. 2, p. 343-353.

Gartner, J.E., Cannon, S.H., Santi, P.M., deWolf, V.G., 2008, Empirical models to predict debris flow volumes generated from recently burned basins in the western U.S.: Geomophology, v. 96, p. 339-354.

Kean, J.W., Staley, D.M., and Cannon, S.H., 2011, In situ measurements of post-fire debris flows in southern California - Comparisons of the timing and magnitude of 24 debris-flow events with rainfall and soil moisture conditions: Journal of Geophysical Research, doi:10.1029/2011JF002005.

Melton, M.A., 1965, The geomorphic and paleoclimatic significance of alluvial deposits in southern Arizona: The Journal of Geology, v. 73, p. 1-3.

Schwartz, G.E., and Alexander, R.B., 1995, Soils data for the conterminous United States derived from the NRCS State Soil Geographic (STATSGO) data base: U.S. Geological Survey Open-File Report 95-449. (Also available at http://water.usgs.gov/lookup/getspatial?ussoils.) 